\title{
Pendidikan Seni Musik Humanis \\ (Suatu Tinjauan Konseptual)
}

\author{
Desyandri \\ Dosen PGSD FIP UNP \\ E-mail: desyandri@yahoo.co.id
}

\begin{abstract}
Abstrak
Artikel ini merupakan analisis kritis yang didasarkan pada beberapa perspektif filosofis, humanis, dan konsep pendidikan seni musik. Pendidik sebagai fasilitator dalam perolehan pengetahuan, keterampilan, dan perilaku positif dengan memperhatikan keunikan dan karakter masing-masing peserta didik dengan memberikan pengalaman berekspresi, berapresiasi, berkreasi, membentuk harmonisasi, dan keindahan, dalam rangka menumbuhkan kesadaran, kemandirian, dan tanggung jawab yang tinggi. Pendidikan seni musik humanis dilaksanakan secara menyeluruh agar peserta didik dapat memahami dan mengambil makna dari belajar bermusik. Untuk dapat melakukan tugas tersebut pendidik seni musik humanis dapat mengandalkan perasaan cinta.
\end{abstract}

Kata Kunci: $\quad$ filosofi, pendidikan, seni musik, humanis

\begin{abstract}
This article is a critical analysis based on some philosophical perspective, humanists, and the concept of musical arts education. Educator as a facilitator in the acquisition of knowledge, skills and positive attitudes with respect to the uniqueness and character of each student by providing the experience of expression, appreciates, creative, forming harmony, and aesthetic, in order to araise awareness, independence, and high responsibility. Humanist musical arts education implemented fully so that learners can understand and take meaning from learning music. To be able to perform the task of music humanist educators can rely on feelings of love.
\end{abstract}

Keywords: philosophy, education, art, music, humanist 


\section{A. Pendahuluan}

Seni musik sebagai salah satu bidang kajian dalam pendidikan seharusnya menunjukkan peranan pentingnya dalam memberikan pengalaman-pengalaman kepada peserta didik dengan kesempatan dan kemampuan untuk berekspresi (expression), berapresiasi (appreciation), berkreasi (creation), membentuk harmoni (harmony), dan kesempatan untuk menciptakan keindahan (aesthetics) dalam hidup dan kehidupan baik terhadap kehidupan pribadi maupun kehidupan dalam lingkungan masyarakat seharihari. Pendidikan seni musik dapat memberikan kesempatan dan pengalaman pada peserta didik dalam rangka mengembangkan kepribadian menuju manusia Indonesia seutuhnya, seperti yang tertuang dalam tujuan pendidikan nasional Inonesia.

Melalui rasa bermusik (sense of music) dan pengalaman berseni (experience of art) peserta didik dapat membekali diri dengan pengetahuan (knowledge), keterampilan (skill), dan perilaku (attitude) yang akan mereka pergunakan dalam menjalani dan memecahkan permasalahan kehidupan sehari-hari, dan sekaligus mengembangkan kepribadiannya. Hal ini, tentunya dapat diperoleh dengan pendidikan seni musik yang dilaksanakan dengan sepenuhnya dan mengakomodir perbedaan karakter, keunikan, dan tingkat perkembangan masing-masing individu peserta didik.

Pendidikan seni musik dilakukan untuk mengembangkan kepribadian peserta didik sesuai dengan kodratnya sebagai manusia seutuhnya (humanity) yang memiliki kebebasan, kematangan diri dan memiliki tanggung jawab yang tinggi secara etika dan moral. Kepribadian yang diharapkan adalah kepribadian yang humanis yang merupakan keseluruhan pola pikiran, perasaan dan perilaku yang digunakan peserta didik dalam rangka adaptasinya dengan kehidupan sehari-hari yang dilandasi dengan kasih sayang (attachment) dan diperlakukan seperti layaknya manusia (human being). Humaniti, tidak hanya sebatas menguasai pengetahuan, akan tetapi penguasaan secara keseluruhan yang berdampak pada kematangan dan perkembangan kepribadian dalam keindahan sikap dan perilaku peserta didik.

Ardipal (2010) dalam jurnalnya mengemukakan tentang tujuan pendidikan seni musik humanis, yakni:

The goal of humanistic art education is to build a conducive atmosphere for learning and learning activities as self-exploration activities. To develop the potential of the learners, the renewal of education and learning for the sake of increasing the professionalism of educators is needed. Therefore, improvement of professional skills education should be directed at fostering professional skills as well as coaching commitments. The improvement of professional capacity of 
educators through the concept of educational reform is more directed to cultured education and grown as a whole.

Tujuan pendidikan seni humanistik adalah untuk membangun suasana belajar dan pembelajaran yang kondusif dalam kegiatan eksplorasi diri. Untuk mengembangkan potensi peserta didik, pembaruan pendidikan dan pembelajaran yang diperlukan untuk meningkatkan profesionalisme pendidik. Oleh karena itu, peningkatan keterampilan profesional pendidikan harus diarahkan untuk membina keterampilan profesional serta berkomitmen terhadap pembinaan. Peningkatan kapasitas profesional pendidik melalui konsep reformasi pendidikan lebih diarahkan pada pendidikan yang berbudaya dan tumbuh secara keseluruhan.

Fakta yang terlihat di lapangan belum menunjukkan sepenuhya pelaksanaan pendidikan seni musik humanis. Hal ini dapat digambarkan, bahwa pendidikan seni musik masih diberikan separo-separo dan masih belum mengakomodasi beberapa pengalaman dan kemampuan-kemampuan dalam berekspresi, berapresiasi, berkreasi, harmoni, dan estetika, serta pembelajaran belum memperhatikan keunikan, karakteristik, dan tingkat perkembangan individual masing-masing pesera didik. Kondisi seperti ini dapat dijelaskan bahwa pendidikan seni musik yang dilakukan hanya sebatas menghafal notasi musik, lagu, dan masih sebatas hiburan untuk menghilangkan kejenuhan peserta didik atau dengan kata lain pembelajaran seni musik yang dilakukan hanya sebatas ranah pengetahuan dan hiburan saja. Kondisi pembelajaran seperti ini belum sepenuhnya dan berdampak pada tidak terpenuhinya hakekat pembelajaran, serta mengabaikan tujuan pembelajaran seni musik itu sendiri. Sehingga pembelajaran belum mengakomodir pengembangan kepribadian peserta didik.

Di sisi lain pendidikan seni musik belum memberikan kebebasan dan kematangan manusia sebagai individu, subjektivitas. Pendidikan belum berusaha untuk menumbuhkan rasa kesadaran diri dan tanggung jawab yang tinggi pada diri peserta didik. Hal ini dapat tergambar bahwa pendidik yang masih mendominasi pemilihanpemilihan materi, menentukan contoh musik atau lagu yang akan dipelajari, memberikan definisi terhadap apa yang dipelajari, serta kegiatan refleksi pembelajaran masih ditentukan oleh pendidik, dan penilaian yang belum didasarkan pada keunikan dan karakteristik pribadi peserta didik.

Pendidik masih memposisikan dirinya sebagai satu-satunya sumber pengetahuan dan belum memposiskan dirinya sebagai fasilitator dan pembimbing yang membantu peserta didik dalam mengarahkan peserta didik untuk mampu bermusik dan 
menumbuhkan emosional, serta mendekatkan mereka dengan alam semesta, lingkungan, serta kehidupan yang akan menumbuhkan rasa kesadaran diri dan tanggung jawab yang tinggi sebagai manusia seutuhnya.

Berasarkan permasalahan di atas, pendidikan seni musik perlu membenahi diri dalam meningkatkan pelaksanaan pendidikan dan untuk memfasilitasi peserta didik dalam rangka menumbuhkan kesadaran diri dan tanggung jawab yang tinggi sebagai manusia (human being). Untuk itu perlu dilakukan pembaruan (renewal) terhadap pendidikan dengan melaksanakan Pendidikan Seni Musik Humanis.

\section{B. Pembahasan}

Berikut ini akan dipaparkan pemikiran kritis dan analitis terhadap konsepkonsep pendidikan dan perspektif filsafat yang diabstraksikan dalam mewujudkan pendidikan seni musik humanis.

\section{Filosofi, Pendidikan, dan Seni Musik}

\section{a. Perspektif Plato's}

Pandangan Plato tentang musik dalam Seymour \& Harriet Ayer (1920:164) yang mengatakan bahwa, "Music is a moral law. It gives soul to the universe, wings to the mind, flight to the imagination, and charm and gaiety to life and to everything”. Musik adalah hukum moral. Ini memberi jiwa ke alam semesta, sayap untuk pemikiran, terbang untuk imajinasi, pesona, keceriaan untuk hidup, dan segala sesuatunya. Ini adalah esensi keteraturan dan menyebabkan semua yang baik, adil, dan indah- yang itu adalah tak terlihat tapi tetap menyilaukan, bergairah, dan bentuk eksternal.

Pendapat tersebut menggambarkan bahwa seni musik merupakan bahasa emosi manusia terhadap alam semesta baik alam itu sendiri maupun manusia yang menghuni alam tersebut yang memiliki akal dan pikiran serta imajinasi untuk tetap menjalani kehidupan sehari-hari dengan ekpresi, sikap dan perilaku yang saling menghargai (apresiasi), serta berusaha untuk membentuk harmonisasi atau keseimbangan. 
Pendidikan seni musik dapat mengarahkan emosional peserta didik untuk mengeksplorasi akal, pikiran, serta imajinasi untuk tetap dekat dengan alam kehidupan sehari-hari dan dapat memfasilitasi atau membimbing peserta didik dalam memahami gajala-gejala yang terlihat di alam semesta serta membimbing mereka memecahkan permasalahan-permasalahan yang terkait dengan kehidupan sehari-hari.

Selanjutnya pandangan Plato tersebut dikembangkan lagi oleh Friedmann (1980:100) yang mengatakan bahwa:

Music is the language of emotion. Emotion is connected with thought. Thought is connected with action, action deals with conduct, and the sphere of conduct is connected with morals. Therefore, ladies and gentlemen, if music is connected with emotion, and emotion is connected with thought, and thought is connected with action, and action is connected with the sphere of conduct, or with morals, things which are connected by the same must be onnected with one another, and therefore music must be connected with morals.

Musik adalah bahasa emosi dan emosi selalu terhubung dengan pikiran manusia. Dan pemikiran akan terhubung dengan tindakan (action), tindakan berkaitan dengan perilaku, dan bidang perilaku terhubung dengan moral. Oleh karena itu, jika musik terhubung dengan emosi, dan emosi terhubung dengan pikiran, dan pikiran terhubung dengan tindakan, dan tindakan yang berhubungan dengan bidang perilaku, atau dengan moral, hal ini menandakan bahwa seni musik memiliki keterhubungan yang sama moral. Dan hal ini akan melahirkan budaya pada masing-masing individu manusia yang mewakili karakteristik mereka sendiri. Karakteristik budaya manusia inilah yang berbaur dalam sebuah kelas dalam persekolahan. 


\section{b. Perspektif John Dewey}

John Dewey (1916:18) telah meletakkan dasar-dasar pemikiran pendidikan yang humanis. Inti pemikirannya adalah bahwa kelas seharusnya cerminan masyarakat yang lebih luas dan berfungsi sebagai laboratorium untuk belajar kehidupan nyata. Dalam proses pembelajaran guru hendaknya membangun lingkungan sosial belajar yang dicirikan dengan prosedur demokrasi dan proses ilmiah. Tanggungjawab guru adalah memotivasi siswa agar belajar secara kooperatif dan untuk memikirkan hal-hal penting di tengah-tengah masyarakat nanti. Di samping itu upaya pemecahan masalah di dalam kelompok kecil mereka, siswa belajar prinsip-prinsip demokrasi melalui interaksi setiap hari di antara mereka.

Sekolah atau universitas seharusnya dapat mencerminkan masyarakat secara luas dan berfungsi sebagai sasana (tempat) untuk mempelajari situasi masyarakat nyata di kehidupan sehari-hari. Perlunya membangun lingkungan sosial yang mencirikan demokrasi dan proses ilmiah. Memberikan kesempatan untuk berpartisipasi dan berinteraksi dalam kerja kelompok dalam mengidentifikasi dan memahami permasalahan-permasalahan kehidupan seharihari.

Pendidikan seni musik dapat memberikan kesempatan dan pengalaman kepada peserta didik dalam permainan musik secara ansambel (bermain musik secara bersama-sama) tentang materi atau konten yang berhubungan dengan religi, kehidupan, keaneka ragaman, dan keindahan alam semesta, diantaranya ansambel musik: lagu anak-anak (seperti lagu Desaku, Di Timur Matahari, Indonesia Pusaka, dan lain-lain), lagu-lagu keagamaan (religi) yang memperlihatkan kekuasaan sang pencipta atau meningkatkan hubungan dengan Allah, lagu-lagu daerah nusantara, seperti Kampuang Nan Jauah Di Mato dan lain-lain. Sehingga peserta didik dapat mengekspresikan, mengapresiasi, berkreasi, mengenal, dan memahami manusia sebagai makhluk Tuhan, serta memahami keindahan alam dan keaneka ragaman budaya yang ada di nusantara.

\section{c. Pespektif Pestalozi's}

Menurut perspektif ide-ide pendidikan Pestalozi yang dikemukakan oleh M.R. Heafford (1967:41-42) mengemukakan bahwa "Untuk mengganti metode lama, Pestalozzi ingin memperkenalkan sistem pendidikan baru yang akan 
memperhatikan anak sepenuhnya, apa yang dapatkan secara mental dan fisik, dan apa yang dia dapatkan dalam pengalaman kejiwaan. Sementara mengingat masa depan anak-anak menuju kehidupan dewasa, pendidikan menjadi berpusat pada anak (child centered) dan beradaptasi dengan kecerdasan, perasaan, dan antusiasme dari anak-anak".

Metode adalah sebuah konsep filosofis, nilai akhir, yang mungkin dapat didefinisikan sebagai metode yang ideal dalam mengembangkan kepribadian anak-anak dan kapasitas secara penuh dan mempersiapkan mereka untuk menjalani kehidupan yang penuh dan bahagia seperti orang dewasa. Tentu saja, definisi tersebut tidak terlalu mengungkapkan, tetapi itu tidak mengungkapkan dua fitur metode Pestalozzi. Pengakuan ideal yang setiap upaya seharusnya dijadikan pendekatan; penerimaan pasif yang ada dari bentuk-bentuk lama seharusnya diganti dengan minat aktif dalam bidang pendidikan. Struktur masyarakat berubah dan pendidikan dapat dan seharusnya memainkan peranan penting dalam perubahan ini. Fitur kedua yang perlu ditekankan adalah pendekatan empiris terhadap pendidikan yang diperbolehkan oleh sistem di mana tidak ada batas-batas tertentu.

Pendidikan seni musik diberikan dengan menggunakan metode-metode baru yang mengakomodir peserta didik sebagai individu atau manusia yang belajar untuk kepentingan hidup mereka sendiri. Untuk itu pendidikan dapat menggunakan pendekatan-pendekatan pembelajaran yang mengacu atau terpusat pada peserta didik (student centered) dalam artian memfasilitasi dan mendorong peserta didik dalam memberikan kesadaran akan diri dan citra mereka secara menyeluruh dalam kehidupan, pendidikan seni musik tidak membuat peserta didik pasif akan tetapi mendorong mereka untuk aktif baik dari sisi mental ataupun fisik, serta mengutamakan fitur pengalaman-pengalaman.

\section{d. Perspektif Humanism}

Lamont (1997:3) mengemukakan tentang esensi perspektif humanisme terhadap kehidupan manusia di atas bumi ini. Lamont mengatakan:

Since the earliest days of philosophic reflection in ancient times in both East and West thinkers of depth and acumen have advanced the simple proposition that the chief end of human life is to work for the happiness of humans upon this earth and within the confines of the Nature that is our home. This philosophy of enjoying, developing, and making available to 
everyone the abundant material, cultural, and spiritual goods of this natural world is profound in its implications, yet easy to understand and congenial to common sense. This human-centered theory of life has remained relatively unheeded during long periods of history. While it has gone under a variety of names, it is a philosophy that I believe is most accurately designated as Humanism.

Sejak awal refleksi filosofis kuno dalam kedalaman dan ketajaman antara pemikiran Timur dan Barat, telah mengembangkan preposisi sederhana bahwa tujuan utama dari kehidupan manusia adalah untuk bekerja untuk kebahagiaan manusia atas bumi ini dan dalam batas-batas alam yang merupakan tempat kita hidup. Filosofi ini menikmati, mengembangkan, dan membuat ketersediaan untuk semua orang tentnag materi yang berlimpah, budaya, dan spiritual dari dunia ini adalah alam yang mendasar dalam implikasinya, namun mudah dimengerti dan menyenangkan dengan akal sehat. Teori yang berpusat pada kehidupan manusia tetap relatif diabaikan selama periode panjang sejarah. Meskipun telah berbagai nama, itu adalah filosofi yang paling akurat dan dikategorikan sebagai Humanisme.

Pada bagian lain Lamont (1997:12-15) juga mengemukakan tentang perspektif historis filosofi Humanism:

The philosophy of Humanism represents a specific and forthright view of the universe, the nature of human beings, and the treatment of human problems. The term Humanist first came into use in the early sixteenth century to designate the writers and scholars of the European Renaissance. Contemporary Humanism includes the most enduring values of Renaissance Humanism, but in philosophic scope and significance goes far beyond it.

Filsafat Humanisme merupakan pandangan yang spesifik dan kejujuran terhadap alam semesta, sifat manusia, dan solusi masalah manusia. Istilah humanis pertama mulai dipakai pada awal abad keenam belas untuk menetapkan para penulis dan sarjana dari Renaisans Eropa. Humanisme kontemporer meliputi nilai-nilai yang paling abadi dari Humanisme Renaissance, tetapi dalam lingkup filsafat dan signifikansi jauh lebih luas dari hal itu.

Pemikiran fisluf humanisme merupakan pandangan yang spesifik terhadap alam semesta, sifat-sifat manusia, dan pemecahan permasalahan-permasalah yang terkait dengan manusia. Hal itu meliput nilai-nilai yang abadi dan segala sesuatu yang jauh lebih laus dari hal itu. Jika dikaitkan dengan pendidikan yang humanis dapat diarikan bahwa pendidikan humanis berkaitan dengan manusia yang 
berkaitan dengan alam semesta dan segala permasalahan-permasalahan yang dilalui. Jadi pendidikan humanis bertujuan untuk membantu manusia dalam menjalani dan menyelesaikan permasalahan-permasalahan hidup.

Terkait dengan penjelasan tersebut, pendidikan seni musik seharusnya bersumber dari alam semesta, tentang liku-liku sifat manusia, dan permasalahanpermasalahan yang terjadi dalam hidup dan kehidupan sehari-hari. Sehingga dapat memfasilitasi peserta didik dalam memahami alam, sifat-sifat manusia, dan permasalahan-permasalahan yang dihadapi manusia dalam hidup dan kehidupan.

\section{e. Perspektif Eksistensialisme}

Gutek (1974:206) mengemukakan pendidikan eksistensialis akan memegang kebebasan manusia sebagai perhatian pentingnya, menekankan individu, subjektivitas. Pendidik eksistensialis berusaha untuk menumbuhkan rasa kesadaran diri dan tanggung jawab pada siswa. Dengan membuat pilihan-pilihan pribadi yang signifikan, dan siswa yang membuat definisi dirinya. Tujuan pendidikan semacam tidak dapat ditentukan di muka dan tidak dapat mereka diberikan oleh guru atau sistem sekolah. Setiap orang memiliki tanggung jawab untuk pendidikan sendiri.

Pandangan filsafat eksistensialisme dapat diartikan bahwa manusia sebagai individul dalam kehidupan merupakan hal yang penting untuk direspon. Hal ini mengindikasikan bahwa pendidikan mengakomodiasi kepentingan dan kebebasan individu peserta didik dalam mengatur hidup dan kehidupan mereka sendiri yang didasari dengan rasa ranggungjawab yang tinggi. Dengan kata lain pendidikan dapat mengakomodir kemandirian peserta didik yang bertanggung jawab atas tindakan dan keputusannya sendiri.

Pendidikan seni musik sebagai bidang kajian dalam pengembangan kepribadian peserta didik dapat memfasilitasi dan membantu peserta didik dengan mengakomodir kebebasan, kemandirian individu peserta didik dalam pembelajaran sebagai modal mereka dalam menjalani kehidupan di alam semesta ini dan dibekali dengan rasa tanggung jawab yang tinggi atas setiap pengambilan keputusan yang dilakukan peserta didik. 


\section{Pendidikan Humanis}

Simpson (1976) dalam E. H. Robinson III; Karyn Dayle Jones and B. Grant Hayes (2000) menggambarkan pendidikan humanistik sebagai lanjutan dari tradisi integratif humaniora:

The search for the good life with balance among the experience of feelings, the explanation of reason, and the implementation of action ... affect and cognition, feelings and intellect, emotion and behavior blend in an affirmative framework of nature derived from the humanistic and from [the] positive conception of mental health, (p. 16)

Pencarian untuk kehidupan yang baik dengan keseimbangan antara pengalaman perasaan, penjelasan alasan, dan pelaksanaan tindakan ... campuran afeksi dan kognisi, perasaan dan intelektual, emosi dan perilaku dalam kerangka afirmatif dengan alam yang berasal dari humanistik dan dari konsepsi positif kesehatan mental.

Manusia adalah makhluk multidimensional yang dapat ditelaah dari berbagai sudut pandang. Spranger (1950) dalam Ardipal (2010), melihat manusia sebagai makhluk jasmani dan rohani. Yang membedakan manusia dengan makhluk lain adalah aspek kerohaniannya. Manusia akan menjadi sungguh-sungguh manusia kalau ia mengembangkan nilai-nilai rohani (nilai-nilai budaya), yang meliputi: nilai pengetahuan, keagamaan, kesenian, ekonomi, kemasyarakatan dan politik.

Atkinson (1983: 417) menyatakan kepribadian sebagai pola perilaku dan cara berpikir yang khas, yang menentukan penyesuaian diri seseorang terhadap lingkungannya. Khas yang dimaksud adalah konsistensi perilaku bahwa orang cenderung untuk bertindak atau berpikir dengan cara tertentu. Dengan demikian kepribadian dapat diartikan sebagai ekspresi ke luar dari pengetahuan dan perasaan yang dialami seseorang secara subyektif. Kepribadian merujuk pada keseluruhan pola pikiran, perasaan dan perilaku yang digunakan seseorang dalam usaha adaptasinya. Kepribadian humanis adalah keseluruhan pola pikiran, perasaan dan perilaku yang digunakan seseorang dalam usaha adaptasinya dengan dilandasi kasih sayang (human being). Humanis, tidak hanya menguasai pengetahuan, tetapi juga berkembang dalam keindahan dan moral, diantaranya: orang yang mengerjakan tugasnya dengan baik dan berperilaku baik. Itulah ide pendidikan humanis yang landasannya adalah moral/nilai.

Rudolf Steiner (2004:1) juga mengemukakan tentang pendidikan humanis dalam pandangan pendidikan dan pengajaran Antroposopis, yakni: 
Anthroposophic education and teaching is based on knowledge of the human being, which is acquired only on the basis of spiritual science; it works from our knowledge of the whole human being as body, soul, and spirit. Initially, such a statement may be seem obvious. It will be said that, of course, the whole person must be considered when it comes to education as an art-that spirit should not be neglected in favor of the physical, nor should the physical be neglected in favor of spirit. The situation will soon be obvious, however, once we see the practical results that arise from any area of human activity that is based on spiritual science.

Pendidikan dan pengajaran anthroposophic yang didasarkan pada pengetahuan tentang manusia, yang diperoleh hanya atas dasar ilmu spiritual, hal itu bekerja dari pengetahuan kita terhadap seluruh keberadaan manusia sebagai tubuh, jiwa, dan roh. Awalnya, pernyataan seperti itu mungkin tampak jelas. Ini dapat diartikan bahwa, manusia seutuhnya harus dipertimbangkan ketika datang ke pendidikan sebagai sebuah seni - yang seharusnya tidak mengabaikan spirit (semangat) dalam mendukung fisik, atau sebaliknya. Situasi akan segera menjadi jelas, bagaimanapun, sekali kita melihat praktis. Hasil yang muncul dari setiap bidang kegiatan manusia yang berdasarkan ilmu spiritual.

Pendapat ini menjelaskan bahwa ilmu pengetahuan yang didapatkan manusia dalam hidup dan kehidupan ini berasal dari kekuatan spiritual yang akan memberikan pedoman bagi manusia dalam mendukung aktivitas fisik maupun mental. Jadi pendidikan seharusnya selalu memberikan peluang atau kesempatan kepada peserta didik untuk mengenal Tuhan sebagai maha pencipta yang memberikan akal dan pikiran dalam memperoleh pengetahuan dan menyeimbangkan antara kecerdasan spiritual dengan kecerdasan intelektual dan kecerdasan emosional. Dengan kata lain pendidikan humanis dapat dilakukan dengan menggabungkan beberapa kecerdasan, seperti keseimbangan kecerdasan intelektual dengan kecerdasan emosional dan spiritual (ESQ).

Rudolf Steiner (2004:6) mengemukakan tentang nilai-nilai kemanusiaan dalam pendidikan bahwa:

In general, people have the idea that love is the most subjective thing there is in life, and that it would be impossible for anyone to love and be objective at the same time. Consequently, when people speak of knowledge today, love is never mentioned in a serious way. True, when young people apply themselves to acquiring knowledge, it is considered appropriate to encourage them to do so with love, but this is usually done while the whole presentation of knowledge is very unlikely to develop love in anyone. In any case, the essence of love-giving oneself to the world and its phenomena-is certainly not 
considered to be knowledge. Nevertheless, for real life, love is the greatest power of knowledge. And without this love, it is impossible to acquire knowledge of the human being, which forms the basis of any true art of education.

Secara umum, manusia memiliki gagasan bahwa cinta adalah hal yang paling yang subjektif dalam kehidupan, dan bahwa hal itu akan menjadi mustahil bagi siapapun untuk mencintai dan menjadi tujuan di waktu yang sama. Akibatnya, ketika orang berbicara tentang pengetahuan, cinta tidak pernah disebutkan secara serius. Benar, ketika orang/anak muda menerapkan diri untuk memperoleh pengetahuan, itu dianggap tepat untuk mendorong mereka untuk melakukannya dengan perasaan cinta, tetapi hal ini biasanya dilakukan sementara seluruh presentasi pengetahuan sangat mungkin untuk mengembangkan cinta pada siapa pun. Dalam kasus apapun, esensi cinta - memberikan diri kepada dunia dan yang fenomena - tentu tidak dianggap sebagai pengetahuan. Namun demikian, untuk kehidupan nyata cinta adalah kekuatan terbesar dari pengetahuan dan tanpa cinta ini, adalah mustahil untuk memperoleh pengetahuan tentang manusia, yang merupakan dasar dari seni pendidikan sejati.

Pendapat ini mengemukakan bahwa pendidikan yang dilaksanakan akan berhasil apabila didasari dengan perasaan cinta. Perasaan cinta yang diberikan pada peserta didik dalam mendorong mereka melakukan aktivitas dan mencapai tujuan dalam pendidikan memerlukan perasaan cinta. Perasaan cinta yang diberikan pendidik, perasaan cinta yang ditumbuhkan peserta didik. Kedua perasaan cinta ini akan menemukan dan mendorong untuk pemerolehan pengetahuan, sehingga pendidikan menjadi sebuah pekerjaan yang disenangi.

\section{Seni Musik dalam Perspektif Filsafat Pendidikan}

Menurut Gutek (1974:204-205) perspektif eksistensialisme menggambarkan bahwa "Seni, kajian yang dirancang untuk menumbuhkan pengalaman estetis, termasuk bentuk-bentuk seperti musik, drama, tari, menulis kreatif, lukisan, dan film. Tujuan pendidikan estetika, menurut eksistensialis tersebut, bukan untuk meniru gaya artis model yang dipilih, meskipun ini mungkin dipelajari, melainkan untuk merangsang ekspresi estetika. Dalam dimensi estetika pendidikan, peran guru adalah untuk membangkitkan dan merangsang rasa pelajar dan keinginan untuk ekspresi estetika. Meskipun tidak mengetahui apa yang pelajar akan ciptakan, guru 
menyediakan berbagai media kreatif sehingga pelajar akan memiliki bahan baku untuk membuat objek seni sendiri. Pelajar menggunakan berbagai media untuk menggambarkan dunia saat ia memandangnya dalam kesadaran sendiri dan menghasilkan karya seni yang berasal dari pusat pengalaman pribadinya".

Menurut Nooryan Bahari (2008:55) mengatakan bahwa seni musik atau seni suara adalah seni yang diterima melalui indera pendengaran. Rangkaian bunyi yang didengar dapat memberikan rasa indah manusia dalam bentuk konsep pemikiran yang bulat, dalam wujud nada atau bunyi lainnya yang mengandung ritme dan harmoni, serta mempunyai bentuk dalam ruang dan waktu yang dikenal oleh diri sendiri dan manusia lain dalam lingkungan hidupnya, sehingga dapat dimengerti dan dinikmati. Selain itu, musik juga dapat membei rasa puas bagi yang mendengarnya karena ada keserasian susunan dari rangkaian tangga nada bunyi-bunyi tersebut. Hal inilah yang akan mempengaruhi perilaku individu baik sebagai pelaku atau penikmat musik itu sendiri, yang nantinya akan berdampak pada terciptanya pengalaman hidup baru dan berdampak terhadap hasil pemikiran dan budaya manusia itu sendiri.

Hal terserbut diperjelas lagi oleh Nooryan Bahari (2008:47) yang mengatakan bahwa dilihat dari sudut pedoman, estetika dan sistem simbol memberi pedoman terhadap berbagai pola perilaku manusia yang berkaitan dengan keindahan, yang pada dasarnya mencakup kegiatan berkreasi dan berapresiasi. Pertama, estetika dan sistem simbol menjadi pedoman bagi seniman untuk mengekspresikan kreasi artistiknya, dan berdasarkan pengalamannya mampu memanipulasi media guna menyajikan karya seni. Kedua, estetika dan sistem simbol memberi pedoan bagi penikmat atau pemakai seni (konsumen) untuk mencerap karya seni tersebut, yang berdasarkan pengalaman mereka dapat melakukan apresiasi dengan menyerap karya seni untuk menumbuhkan kesan-kesan atau pengalaman estetika tertentu. 
Rien (1999:1) mengemukakan mengenai pendapat para pakar pendidikan berpendapat bahwa seni musik mempunyai peranan yang penting dalam kehidupan seorang peserta didik. Peserta didik yang berpartisipasi dalam kegiatan seni musik, selain dapat mengembangkan kreativitas, musik juga dapat membantu perkembangan individu, mengembangkan sensitivitas, membangun rasa keindahan, mengungkapkan ekspresi, memberikan tantangan, melatih disiplin dan mengenalkan peserta didik pada sejarah budaya bangsa mereka.

Menette Mans (2009:19) mengemukakan tentang praktik musik bahwa:

Musical practice is also the result of layers of individual experience musical trials and errors within specific contexts or situations - that have been socially refined, reflected upon, practiced, and remembered over a period of time, all the while undergoing small adjustments and changes. Within a group, the musical functions are more complex than in the performance of an individual. A group has to meet the aesthetic needs not only of an audience or onlookers but also within the group. Through their musical interactions and communications, they try to reach beyond good, to transcend as a group.

Praktek musik juga merupakan hasil dari pengalaman individu - trials and error musik dalam konteks atau situasi tertentu - yang telah disempurnakan secara sosial, direnungkan, dipraktekkan, dan diingat selama periode waktu, sambil menjalani penyesuaian kecil dan perubahan. Dalam kelompok, memberikan fungsi musik yang lebih kompleks daripada kinerja individu. Kelompok untuk memenuhi kebutuhan estetika tidak hanya dari penikmat atau penonton tetapi juga dalam kelompok itu sendiri. Melalui musik mereka berinteraksi dan berkomunikasi, mereka mencoba untuk mencapai yang lebih baik, untuk hal yang lebih penting dari sekedar sebuah kelompok.

Hal ini memberikan gambaran bahwa praktik musik dapat dilakukan secara individual maupun secara bersama atau berkelompok. Penekanan pada permainan berkelompok merupakan permainan musik yang memberikan pengalaman interaksi 
dan komunikasi dalam kelompok itu sendiri. Dengan adanya permainan berkelompok tersebut dapat menggambarkan adanya proses penyesuaian diri atau adaptasi sesama anggota kelompok, yang secara tidak langsung mereka sudah tergabung ke dalam penyesuaian atau adaptasi dengan budaya yang beragam dalam sebuah kelompok pertunjukan musik. Mereka memerlukan kesadaran untuk memahami budaya dari masing-masing anggota dalam satu kelompok atau dalam lingkungan penampilan musik tersebut. Sehingga akan terciptalah keharmonisan atau keseimbangan dalam permainan musik yang secara tidak langsung telah memberikan pengalaman pada individu untuk dapat menciptakan suatu kesejajaran, baik itu dalam permainan musik mereka maupun pengaplikasian hal tersebut dalam kehidupan mereka sehari-hari.

Secara konseptual pendidikan seni musik dapat memberikan bekal pengalaman kepada peserta didik untuk dapat membentuk interaksi, komunikasi, keadilan, kesetaraan, keharmonisan, dan keindahan dalam keberagaman karakteristik individu (pemain) dan keberagaman bentuk alat musik yang terlibat dalam sebuh performan musik. Hal ini jelas menggambarkan suatu perpaduan budaya yang berbaur menjadi satu dengan mempertimbangkan azas keharmonisan dan keindahan.

Menurut Nooryan Bahari (2008:47) mengatakan bahwa dilihat dari sudut pedoman, estetika dan sistem simbol memberi pedoman terhadap berbagai pola perilaku manusia yang berkaitan dengan keindahan, yang pada dasarnya mencakup kegiatan berkreasi dan berapresiasi. Pertama, estetika dan sistem simbol menjadi pedoman bagi seniman untuk mengekspresikan kreasi artistiknya, dan berdasarkan pengalamannya mampu memanipulasi media guna menyajikan karya seni. Kedua, estetika dan sistem simbol memberi pedoman bagi penikmat atau pemakai seni (konsumen) untuk mencerap karya seni tersebut, yang berdasarkan pengalaman 
mereka dapat melakukan apresiasi dengan menyerap karya seni untuk menumbuhkan kesan-kesan atau pengalaman estetika tertentu.

Menurut Nooyan Bahari (2008:148) bahwa apresiasi seni merupakan suatu proses sadar yang dilakukan seseorang dalam menghadapi dan memahami karya seni. Mengapresiasi adalah sebuah proses untuk menafsirkan sebuah makna yang terkandung dalam karya seni. Pada sisi lain dapat dijelaskan apresiasi sebagai sikap atau perilaku menghargai atau mengadopsi nilai-nilai yang terdapat pada karya seni untuk dijadikan sebagai pedoman dan panduan dalam kehidupan manusia, dan sekaligus menjadi tindakan untuk melestarikan setiap karya seni yang ada.

\section{Pendidikan Seni Musik Humanis}

Beradasarkan beberapa perspektif, konsep dari beberapa pandangan filsafat tentang pendidikan dan seni musik yang dikemukakan di atas, dapat diambil satu benang merah yang menyatakan bahwa pendidikan humanis merupakan pendidikan yang dilaksanakan dalam rangka memandang pentingnya menjadikan peserta didik sebagai manusia seutuhnya dalam membekali dengan kematangan diri dan tanggung jawab tinggi yang memiliki keinginan dan kemandirian dalam menjalani dan menentukan hidup dan kehidupannya di muka bumi ini.

Pendidikan sebagai sasana atau laboratorium dapat melaksanakan peran pentingnya dalam mengakomodir kepentingan manusia untuk dapat memiliki pengetahuan, keterampilan, perilaku positif. Pendidikan memberikan sarana untuk pengembangan pengalaman-pengalaman yang didasarkan pada proses ilmiah dan pemecahan pemasalahan kehidupan sehari-hari.

Pendidikan seni musik yang humanis dapat diartikan sebagai pendidikan seni musik yang memberikan kesempatan atau pengalaman-pengalaman kepada peserta didik melalui unsur-unsur seni seperti berkekspresi, berapresiasi, berkreasi dengan musik, dan dapat membentuk harmonisasi dengan diri sendiri, lingkungan, dan alam semesta, serta memahami pentingnya estetika. Yang pada akhirnya dapat menjadikan peserta didik sebagai manusia. Semua hal itu tercantum dalam tujuan pendidikan seni musik dan dituangkan dalam kurikulum sebagai panduan dalam menyelenggarakan pendidikan yang humanis. 
Peserta didik memiliki kebebasan dalam mengekspresikan dirinya sebagai manusia yang juga memiliki tanggung jawab yang tinggi atas dirinya sendiri yang mengacu pada aturan-aturan pendidikan. Pendidik memegang peranan yang sangat penting dalam memfasilitasi dan membantu peserta didik untuk melakukan proses belajar dan menciptakan pengalaman-pengalaman yang dapat dijadikan sebagai bahan atau bekal bagi peserta didik dalam mengarungi hidup dan kehidupan. Pendidik membantu menumbuhkan kesadaran akan kemandirian, pengambilan keputusan sendiri, dan dapat menumbuhkan tanggung jawab yang tinggi terhadap pemilihan tersebut.

Materi dan konten yang diberikan disesuaikan dengan kebutuhan peserta didik dan terkait dengan perkembangan usia serta kematangan emosionalnya, dan memberikan keseimbangan kecerdasaran intelektual dengan kecerdasan-kecerdasan yang dimulikinya, diantaranya keseimbangan antara kecerdasan intelektual, emosional, dan spiritual. Musik yang dipelajari dapat terkait dengan kebesaran Allah sebagai pencipta manusia dan alam, memperkenalkan bunyi-bunyian yang berasal dari alam atau bunyi-bunyian buatan, keindahan alam, peristiwa alam, kasih sayang, nasehat, bela negara, cinta tanah air, dan memberikan pengalaman untuk mengenal hubungan sosial dan budaya. Dengan arti kata semua materi atau konten yang diberikan diikuti dengan pemaknaan terhadap unsur-unsur yang terdapat pada musik itu sendiri. Misalnya dalam mempelajari dan menyanyikan berbagai macalam lagu daerah, peserta didik dapat berekspresi, mengapresiasi, berkreasi, membentuk harmoni, dan menikmati keindahan musik dan dilanjutkan dengan mengekplorasi makna atau isi lagu yang dinyanyikan. Sehingga lagu tersebut dapat memberikan pemahaman terhadap ciri khas budaya yang terdapat pada masing-masing daerah serta dapat menjadikan peserta didik memahami budaya masing-masing daerah tersebut. Sehingga dari proses mempelajari atau menyanyikan berbagai macam lagu daerah, dapat menumbuhkan kesadaran dan kepedulian diri akan keanekaragaman budaya dan kehidupan yang terdapat di nusantara ini. Sehingga pembelajaran yang dilakukan secara menyeluruh dapat memberikan input bagi peserta didik dengan memberikan haknya sebagai manusia yang hidup dalam beberagaman.

Pemerolehan dan pemberian pengetahuan, skill, dan perilaku dalam bermusik tidak terjadi begitu saja akan tetapi dilandasi dengan proses interaksi yang didasarkan pada perasaan cinta (love) dan kasih sayang (attachment) sebagai pengikat dan memberikan dorongan (motivation) kepada peserta didik. Sehingga pembelajaran 
seni musik yang dilakukan merupakan pembelajaran sepenuhnya dan lebih bermakna (meaningful).

Peran peserta didik dalam pendidikan seni musik humanis adalah dapat mengembangkan kepribadian mereka sesuai dengan kemandiriannya sebagai manusia, menentukan pilihan, mengambil keputusan, dan mengeksplorasi dirinya sendiri dengan keunikan dan karakteristik yang mereka miliki yang berbeda satu sama lain. Misanlnya, dalam mengekspresikan sebuah lagu, mereka memiliki karakter dan gaya sendiri untuk menampilkannya, sehingga tidak sama dengan artis atau penyanyi asal lagu tersebut. Dalam menyanyikan lagu anak-anak yang dipopulerkan oleh Tasya dengan karakter dan gaya Tasya sendiri, maka peserta didik juga mengekspresikan lagu tersebut dengan karakter dan gaya mereka sendiri. Sehingga lagu tersebut terdengar berbeda dari yang aslinya dan memperlihatkan warna peserta didil itu sendiri. Dengan kata lain, yang muncul adalah karakteristik peserta didik bukan karakteristik Tasya.

Dengan demikian pendidikan seni musik humanis dapat memfasilitasi peserta didik untuk menumbuhkan kesadaran diri dan rasa tanggung jawab yang tinggi terhadap diri mereka sendiri. Sehingga dengan proses ekspresi, apresiasi, kreasi, harmoni, dan estetika yang mereka lakukan dapat mengembangkan kepribadian mereka untuk hidup dan kehidupan yang lebih besar di masyarakat dan sebagai warga negara yang baik, serta pendidikan seni musik humanis dapat menjadikan mereka sebagai individu sebagai layaknya manusia.

\section{Simpulan}

Pendidikan seni musik humanis adalah proses pendidikan yang dilakukan dengan mewadahi dan mengakomodir manusia atau peserta didik sebagai manusia yang memiliki kemandirian dalam menentukan keputusan peserta didik dengan memperhatikan berbagai hal tentang usia dan tingkat perkembangan yang terkait dengan manusia sebagai ciptaan Allah SWT.

Pendidik dapat membantu peserta didik dalam memperoleh pengetahuan, keterampilan, dan perilaku positif dengan memperhatikan keunikan dan karakter masing-masing peserta didik dengan memberikan pengalaman berekspresi, berapresiasi, berkreasi, membentuk harmonisasi, dan keindahan, serta memperlakukan dirinya sebagai fasilitator dan pembimbing dalam membantu menumbuhkan kesadaran, kemandirian, dan tanggung jawab tinggi dari peserta didik. Pendidikan dilakukan secara 
menyeluruh agar peserta didik dapat memahami pembelajaran dan mengambil makna dari belajar musik. Untuk dapat melakukan tugas tersebut pendidik sebagai fasilitator dan pembimbing dapat mengandalkan perasaan cinta.

\section{Daftar Rujukan}

Dharsono (Sony Kartika). 2007. Kritik Seni. Bandung: Rekayasa Sains

Friedmann, Jonathan L.. 1980. The Value of Sacred Music; an Anthology of Essential Writings 1801-1918. Jefferson, North Carolina, \& London: McFarland \& Company Inc., Publishers

Gardner, Howard. 2003. Multiple Intelligences; Kecerdasan Majemuk, Teori dalam Praktek. Batam: Interaksara

Gutek, Gerald Lee. 1974. Philosophical Alternatives in Education. Colombus, Ohio; Charles E. Merrill Publishing Company, A Bell \& Howell Company

Hazleton. 2001. Democracy and Education by John Dewey; A Penn State Electronic Classic Series Publication. Pennsylvania University

Heafford, M.R. 1967. Pestalozzi; His Thought and Its Relevance Today. London: Methuen \& CO LTD

Jamalus dan Hamzah Busroh. 1991. Pendidikan Kesenian I (Musik). Jakarta: Departemen Pendidikan dan Kebudayaan Direktorat Jenderal Pendidikan Tinggi Proyek Pembinaan Tenaga Kependidikan.

Lamont, Corliss. 1997. The Philosophy of Humanis; Eighth Edition, Revised. Amherst Newyork. Humanism Press

Mans, Minette. 2009. Living in World of Music; A View of Education and Value. In Lanscape the Art, Aesthetic, and Education. Volume 8. New York: Springer

Nooryan Bahari. 2008. Kritik Seni; Wacana Apresiasi dan Kreasi. Yogyakarta: Pustaka Pelajar

Ramachandran, Sheela dkk. 2008-2009. Value Education - Human Rights; Hand Out. Coimbotare: Bharahtiar University

Rien Syafrina. 1999. Pendidikan Kesenian (Musik). Jakarta: Departemen Pendidikan dan Kebudayaan Direktorat Jenderal Pendidikan Tinggi Proyek Pembinaan Tenaga Kependidikan.

Seymour, Harriet Ayer. 1920. The Philosophy of Music; What Music Can Do For You. Digitized by the Internet Archivein 2008 with funding from Microsoft Corporation. Newyork and London: Harper and Brother Publisher diakses 
tanggal 15/10/2012 dari

http://www.archive.org/details/philosophyofmusi00seymrich

Sheppard, Philip. 2005. Music Makes Your Child Smarter: How Music Helps Every Childs Development. Artemis Music Limited All rights reserved. Dialih bahasakan oleh Henry Wisnu Dewanto. 2007. Music Makes Your Child Smarter: Peran Musik dalam Perkembangan Anak. Jakarta: PT. Gramedia Pustaka Utama

Steiner, Rudolf. 2004. Human Values in Education; 10 Lectures in Arnheim, Holland July 17-24, 1924. Great Barrington: Anthroposophic Press

Stephenson, Joan, dkk. 2005. Value in Eduation. New York: Routledge

Woodford, Paul G. 2005. Democracy and Music Education; Liberalism, Ethics, and the Politic of Practice. Bloomington and Indianapolis: Indiana University Press 